\title{
Managing the Ukrainian crisis: a challenge for European security
}

\section{Introduction}

The conflict in Ukraine - labels vary from "a crisis" to "a hybrid war" - is gradually turning the European security system into ruins. In two years, what was once the most secure continent has been flooded with threats it can hardly handle. Some of these are well-known soft security issues, e.g. illegal human trafficking. However, something else has been added, a complete reframing of the security environment and the resurrection of hard security threats as a result of the revisionist policy carried out by Russia. Not only is Ukraine's sovereignty is stake, but also the very foundations of the regional security arrangements so thoroughly constructed since the end of the Cold War.

\section{Regional Security Damaged: Back to Realpolitik?}

Along with possible future implications, so actively speculated about, Russia's active revisionist policy in Europe and beyond is generating a new reality on the ground in real time. It turns out that President Putin has not so much lost touch with reality, but rather his vision and perception of reality is being actively imposed on the European political agenda. Since politics is not only about material factors, but also ideas and perceptions, the ability to the shape agenda and reframe values is an important power asset. The way this asset is being used currently undermines European security.

The European security system is seriously damaged in several important ways. Each alone is a serious challenge, and the cumulative effect goes far beyond the impact of any other crisis since the end of the Cold War. First of all, fundamental principles of international law are openly violated. The annexation of the Crimea from Ukraine breaches the UN Charter and Helsinki Final Act as well as Russian-Ukrainian Treaty of 1997. As an open act of aggression, it contradicts the non-use of force principle and violates the territorial integrity of a neighboring state. To put it short, Russian aggression calls into question almost every single legal foundation of the current world order. 
Secondly, in addition to international law, it undermines the effectiveness of international norms, regimes, and organizations. To operate effectively they all need stable rules and principles, which are by now in question. The helplessness of the UN as well as the limited effectiveness of regional organizations, most notably OSCE, is the immediate result of the regional security crisis. A more long-term effect would significantly erode mutual trust among European actors.

Thirdly, revisionism carries its own alternative agenda. By undermining wellknown principles and norms of European politics, Russia is putting forward its own vision, which could be labeled realpolitik. It implies spheres of influence, balance of power, and the principle of self-help. If installed, it will take European politics back to mechanisms and instruments of the $19^{\text {th }}$ century. This creates two main problems. First, mismanagement of the multipolar "European concert" in the end resulted in degrading security and the First World War, and there is no guarantee that there would be a better result in the $21^{\text {st }}$ century. Secondly, imperial politics of the $19^{\text {th }}$ century may have provided Russia with additional greatness, but today's regional system is much more complicated and cannot be managed with a Bismarckian-style toolbox.

However, revisionism is quickly bringing about perceptional changes. International actors will have to adapt their expectations, goal-setting, priorities, and general political approaches to new realities. In short, they will have to shift the paradigms of security policy.

Until recently European security has been largely operating under neoliberal and neofunctional theoretical umbrellas. These implied high levels of interdependence, long-term cooperation, and institutionalized partnership as foundations for international security. From a neoliberal point of view, complex interdependence of international actors is capable of partly overcoming international anarchy and thus ameliorating the security dilemma, a triggering mechanism for most international conflicts ${ }^{1}$. When states cooperate repeatedly, they build links of mutual dependence and institutionalize them through international norms and regimes. That means that under conditions of repeated partnership, international actors pursue absolute gains and thus can trust each other even while remaining essentially egoistic agents. Cooperation becomes a dominant interest in such a system, while international security is maintained through a network of international regimes and norms.

In some cases, as neo-functionalism argues, deepened cooperation may result in processes of integration ${ }^{2}$. Cooperation can spillover to various spheres, in particular, into political and security areas. This brings about erosion of state sovereignty and formation of supra-national institutions. The European integration process is an example of such post-Westphalian politics.

R. Axelrod, R. Keohane, Achieving Cooperation Under Anarchy: Strategies and Institutions, "World Politics" 1985, Vol. 38, No. 1, pp. 226-254.

2 N. Lindberg, A. Stuart (eds.), Regional Integration: Theory and Research, Cambridge MA: Harvard University Press, 1971. 
European security has been constructed mostly along these neoliberal and neo-functional lines. Mutual trust, absolute gains, repeated cooperation have been key elements of the security environment. The use of force, arms races, intimidation and blackmail did not pay off and have been mostly marginalized.

Now all that is changing. Direct application of military force combined with a highly revisionist political agenda transforms the very conceptual foundations of security. These transformations are best reflected by the "good old" realist paradigm.

Political realism holds that states with their egoistic national interests are the key agents of international politics. They struggle for security, power, and influence in a highly competitive and hostile environment. Military, strategic, and political realms are most prioritized among all other possible areas of cooperation or competition. States, according to Hans Morgenthau, are "...continuously preparing for, actively involved in, or recovering from organized violence in the form of war." ${ }^{\text {In }}$ In a world like this cooperation becomes a tough choice. Before engaging in it a state must define how exactly it wants mutual gains to be divided. Since today's partner could be tomorrow's adversary, any state would like to get a bigger share of mutual gain. This, in turn, would lead to states' concentration on relative, rather than absolute, gains. Since getting a bigger share is more important than getting any share at all, long-term cooperation under realpolitik thinking becomes limited. International norms and institutions that arise from such cooperation also lose their power. International politics gets back to the state of anarchy. The security dilemma will reemerge as the most powerful driving force behind the security policies of states. It will make states spend more on defense and boost containment strategies. Increasing mistrust and worst-case scenario thinking will follow. All in all, the balance of power mechanism will become the only effective one for maintaining security.

But that would be something quite different than what the EU has been seeking. Instead of European security rooted in mutual benefit, common norms, and interdependence, an old-fashioned balance of power system will emerge, making current security instruments and arrangements obsolete.

\section{Weak States and Frozen Conflicts}

This challenge will be accompanied by two others: the retreat of democracy and increased risk of state failure. Both will be mostly relevant for post-Soviet states, however both will have consequences for the whole European security system.

Attempting to spread its influence in the neighborhood, Russia is pursuing a policy of weakening post-Soviet states. This does not necessarily imply decreasing their military capacities, but mostly is directed at lowering their efficiency by cultivating separatism (Moldova, Georgia, Ukraine), corruption, and economic and energy ineffectiveness. The overall result for such states is increased dependence on Russia's energy, financial resources, and political and military support.

H. Morgenthau, Politics Among Nations, New York 1960, p. 38. 
Russian revisionism, if successful, would further weaken post-Soviet space, in particular in Eastern Europe, and result in a growing authoritarianism in the region. Tightening control over territories is a key element of restoring spheres of influence, and Russian European politics, already highly resembling that of Tsar Nicolas I in the mid- $19^{\text {th }}$ century, will become even more similar quite soon.

States' weakness will have a profoundly negative impact on regional security. By definition, weak states are those unable to deliver the full spectrum of common goods to their citizens ${ }^{4}$. Most importantly, they cannot deliver security to both individuals and social groups. As a result, weak states - and especially failed states - are generating specific environment for internal conflicts, known as the structural security dilemma. This is when a particular social group, ethnic or religious minority, feels threatened and cannot rely on a state for protection, mostly due to its weakness. Under these circumstances minorities and groups mobilize themselves and soon reproduce a classical security dilemma within a particular country. Under normal conditions, there is no anarchy within a state: it possesses a monopoly of violence and settles disputes among citizens. However, as a state weakens and/or fails, it is no longer capable of either providing security or monopolizing violence. As various social groups start taking care of their own security, they face a situation when improving one's own security is perceived as undermining the security of others. Such a perception provokes preventive actions and, in particular, preventive violence. That is how internal conflicts develop in weak states.

Growing ineffectiveness of states is certainly among the key reasons for the current internal conflicts in Eastern Europe. Russia is set to further undermine states in its neighborhood to secure more control over them. It still remains to be seen whether such a strategy will work out, but it is already clear that Eastern Europe has become a much less secure place.

Russia's bet is on controlling internal conflicts in neighboring states and using them for attaining political goals. However, these conflicts tend to acquire their own agenda, dynamics, structure, and logic. They also tend to become protracted and spill over into the neighborhood. In short, they are much easier to trigger than to control. Further weakening of Eastern European states will multiply security challenges.

Another dangerous implication of Russia's regional policy is a possible "retreat of

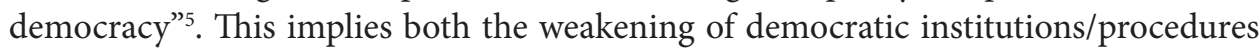
and a decrease in the number of democratic states. Already a trend in regional politics since $2010^{6}$, further "de-democratization" may have a set of negative consequences. First, a democracy deficit usually multiplies the effects of state weakness described above. Authoritarianism promotes discrimination, at the very least political, and thus reinforces the structural security dilemma. Secondly, less democracy usually results

\footnotetext{
R. Rotberg (ed.), When States Fail: Causes and Consequences, Princeton 2003.

5 Democracy Index 2010. Democracy in Retreat. A Report from the Economist Intelligence Unit, https:// graphics.eiu.com/PDF/Democracy_Index_2010_web.pdf., 20.09.2015.
}

6 Ibidem. 
in less security on a bilateral level. A number of regional conflicts, which have already spilled over from state to a bilateral level - most notably the Armenian-Azerbaijani conflict over Nagorno Karabakh and recent Russian-Ukrainian conflict - could have been settled and/or prevented given democratic regimes on all sides. To the contrary, a further retreat of democracy would worsen the environment for conflict management due to a growing level of distrust.

Lack of trust is set to become another challenge with a cumulative security effect. Mutually positive perceptions and expectations are important elements of regional security, as soon as they enable effective functioning of international regimes and organizations and help ameliorate security dilemma in relations among states. Usually, trust in international politics is hard to build and quite easy to ruin. Building trust takes time as it requires repeated cooperation and partnership. An open use of violence quickly destroys trust and shifts perceptions. States no longer rely on common values and norms; neither perceives the other as a partner. Worst-case thinking and relative gains replace all other strategic considerations. That transforms the environment for regional and internal conflicts as well as significantly lowers the potential for international cooperation.

All these normative, strategic, and functional changes are dangerous and capable of significantly worsening the European security environment.

The Ukrainian crisis will surely become a part of a broader security arrangement, in which so-called "frozen conflicts" are distinctive elements.

These conflicts, mostly in latent phase, are unresolved internal disputes, for instance in Moldova and Georgia, characterized by active Russian involvement. Although there are factors, such as state weakness or democracy deficit, contributing to those conflicts, the role of Russia's support for separatists is crucial ${ }^{7}$. Traditionally, the Kremlin has used its stake in these conflicts as a tool for regional policy. By manipulating levels of escalation, it could block certain options for Georgian or Moldovan foreign policy (most importantly NATO membership or closer cooperation with the EU).

Gradually, "frozen conflicts" have become a cornerstone of Russias regional policy and a serious threat to regional security. While Russia aimed at keeping neighboring states under control and thus needed them weak, Europe's strategic interest was making them strong and effective, both economically and politically.

Russia's bet on weak states, authoritarianism, and "frozen conflicts" is a formidable and complex security challenge for Europe. No matter how seductive the Kremlin's offer to tackle it by leaving them within its own "sphere of influence" might be, this is hardly a good solution. A long-term result would be doubling the risks: along with those challenges, Europe will also have to deal with a reinstalled bipolarity and the structural dangers it generates.

7 For more details see M. Kapitonenko, Resolving Post-Soviet "Frozen Conflicts": Is Regional Integration Helpful?, "Caucasian Review of International Affairs" 2009, Vol. 3, No. 1, pp. 37-44. 


\section{A Challenge for Europe}

The European Neighborhood Policy (ENP) needed adjustments well before the Ukrainian crisis turned that need into a necessity. Not only had the Arab Spring created a somewhat new environment for EU security and foreign policy, but also developments in Eastern Europe completely reshaped a set of risks the Union faces. Russia's clear intentions to reinstall sphere of influence over post-Soviet space resulted in a dangerous crisis during the War in Georgia in 2008, the long-term consequences of which have been largely overlooked. Meanwhile, the conflict indicated the Kremlin's readiness to add the traditional tactics of manipulating "frozen conflicts" with new, military, dimension. That, of course, put the whole set of security frameworks in Europe under question. The Eastern Partnership Project (EaP) has been launched under quite unfavorable conditions: its target countries have been heavily dependent on and vulnerable to Russia, while Moscow has been determined to keep them under control. Risks produced by miscalculations of this kind are numerous and already too clear. The situation on the ground has changed radically. The ENP should be adjusted to these changes; otherwise, it will become a source of instability rather than an instrument for enhancing Europe's security.

At the same time, there's no question about maintaining the ENP. It is an important and probably the only way to effectively project the EU's normative and soft power capabilities. The Policy should address needs of target countries, define and secure common interests, and explore fields of possible cooperation. It should also help build up a consolidated policy of the Union in addition to foreign policies of the member-states.

The logic behind the Policy is that EU possesses normative capacity to transform the neighborhood in a way that will be most favorable for ensuring security of the member states. This is an ambitious assumption, but so far there is no alternative to it. Thus, the ENP should address both East and South; however a single normative component should be added with differentiated instruments for each specific case.

In some of those cases the EU will meet the interests of third states. This will not necessarily happen because those states are "neighbors of the neighbors", but because they are regional powers pursuing interests in the neighborhood, just like the EU itself. In such cases this will not be about making these states part of the ENP, but about defining the principles, guiding both the ENP, itself, and the dialogue with external powers.

Russia, as the regional power openly aiming at maintaining its sphere of influence, is certainly the most important of them and requires specific attention and a well-designed strategy. Such strategy should give a clear answer to the question of whether $\mathrm{EaP}$ target countries are free to define their own foreign policies as well as the question of how determined the EU, itself, is in helping them to secure that freedom. With those answers the strategy would become a cornerstone of EU's further policies in the East. The Russian factor is a key reason for separating Eastern and Southern dimensions within a general framework of the ENP, since in the former case the EU would face a geopolitical rivalry in addition to well-known soft security issues.

From a Ukrainian perspective, the best way the EU could support ENP target countries in interactions with their neighbors is through helping them reduce de- 
pendency and vulnerability. More specifically, Ukraine needs access to European markets, effective participation in the European energy system, visa-free regime to build up a more effective economy and get rid of the weak state syndromes so actively exploited by Russia.

Ukraine would welcome continuation and strengthening of a normative component of the ENP. Core values of the European Union should be kept as a foundation of its security policy in general and the ENP in particular. For Ukraine this is even more important after the events of the Euromaidan, where European values became a driving force. But it is also crucial for the EU, itself. Its political and security capabilities are determined and limited by the ability to be a center of gravity for the neighborhood or, in other words, to generate and spread norms. This ability has brought about political success after the Cold War with the area of stability significantly widened. Normative capacity is what brings added value to a sum of member-states' foreign policies and thus makes the EU a truly international actor.

At the same time, adding a geopolitical dimension of security policy to normative foundations will be a hard task, but a necessary one. The EU is facing a totally new challenge to its security, and that is a challenge from a revisionist power on its borders. Even if there is no direct threat, military or political, to EU member-states, Russia's assertive foreign policy may bring about considerable negative consequences. The Kremlin's success in denying Ukraine's right to carry out an independent foreign policy would erode the very foundations of the current security architecture. It will also increase the importance of hard power assets, while decreasing those of soft power. European politics will eventually become a zero-sum game of mutual fear and distrust. The long-built neoliberal foundations of European security would be replaced by realist short-term and worst-case scenario thinking. It would, to some extent, resemble a European concert of the 19th century.

To minimize possible negative consequences, the EU should concentrate on both introducing geopolitical elements into its security policy and elaborating a strategy towards Russia. Balancing geopolitical and normative issues would be challenging. One of the possible ways to do that could be through backing a set of core principles of European security, possibly though dialogue with Russia, that would include freedom of choice for states and no "veto" right for the big powers. The EU could look for the ways to negotiate "rules of the game" with Moscow and enhance abilities and determination to make them work. Ukraine could become an important element of such a strategy.

Another important normative issue to consider is the EU's dialogue with non-democratic states, particularly within the ENP framework. There are certain limitations on how far political cooperation and adopting European norms could go in these cases. When the dialogue reached those limits, the whole logic of association becomes shaky. This is another important argument for making the ENP more targeted.

For the ENP to become an effective political instrument it is necessary to clearly define areas of responsibility for member-states and the Union. The tricky thing is that the more realist international politics in Europe become as a consequence of Russian 
revisionism, the more decision-making would be taking place at the level of the state. On the other hand, if the states are back as key political actors, the whole foreign policy of the European Union may face difficulties. This is one of the most fundamental and long-term difficulties the EU will face as a result of the current crisis. And this is also one of the weakest links in European security policy that is actively exploited by Moscow. By injecting more hard power into European politics, the Kremlin makes supranational structures, mostly effective in normative and soft power issues, obsolete. At the same time this leads to an increased demand for hard power and hard security, a demand most effectively met by states.

With that said, it would be uneasy to define how much involvement from the member states is needed within the ENP. The Policy, itself, should better stay within the frame of the EU's foreign policy, since that would be the best way to provide the normative content. However, more geopolitical reasoning and more realistic foundations would require more active participation by member-states, especially in crisis situations. That is already clear in Ukraine, where the ENP cannot provide quick reactions and responses, and much more involvement from states, namely Germany and France, is necessary. With the general destabilization of the European security system, ad hoc interventions by states may become a way to strengthen the ENP.

At the same time, more involvement from states should not turn the EU's policy into a set of competing policies of its members, thus reestablishing a traditional European geopolitical rivalry. Such involvement should be strictly coordinated and in line with the logic of the ENP, itself. States could provide more leadership and resources, however, avoiding situations where there is a high risk of political division. It is important to define the stakes and responsibilities as clearly as possible. The fundamental problem with the whole EU foreign and security strategy is the overlapping of national and supranational levels in designing and implementing the policy. With the exception of the fundamental normative consensus, member-states often see things in the neighborhood differently and are not similarly affected by the developments on the EU borders. To avoid replacement of the ENP with a set of bilateral initiatives, a division of responsibilities should be drawn to make the policy more credible.

Another way to adjust the ENP would be by introducing a more individualized approach to target countries. Currently they are grouped, mostly geographically, but that is no longer enough. Within the framework of the EaP, there are at minimum two groups of countries with different aspirations and achievements along the path of European integration. However, even that is not enough, given the necessity to react quickly to changes in target countries and to the regional environment in general. Addressing countries individually would certainly require more effort and planning, but in the end it would be more effective.

Sooner or later, a closer association with the EU will raise the question of membership, and in some countries already has. Those seeking more intensive integration implicitly or explicitly have that question in mind, and it is too fundamental to ignore. Within the new ENP a membership perspective should be more clearly defined. It can 
become a powerful tool for reforms, and - in some cases- the only tool. Without a broad consensus in some Eastern European states over reform, the technical and financial instruments currently provided by the EU may prove to be insufficient. A membership perspective, however distant and complicated, could help solve the problem.

\section{Conclusion}

The Ukrainian crisis goes far beyond the country's geographical borders. It poses a complex and multidimensional threat to European security. The open use of violence, resulting in annexing a neighboring state's territory, has undermined the very foundations of world order and European security arrangements.

By pursuing an openly revisionist foreign policy, Russia challenges the ways Europe maintains security. That concerns not only Russia's planned sphere of influence in Eastern Europe, but the whole continent.

The best response to this challenge would include 1) raising diplomatic, political, and economic pressure on the Kremlin, and 2) modifying criteria for NATO membership in such a way that contested territories are no longer prevented from joining the Alliance. Such a combination would deprive Russia's strategy most of its rationale and further increase its costs. In both cases Ukraine can be an important solution.

Obviously, decision-makers in the Kremlin believe that military backing of a puppet government in Transnistria in 1992, aggression against Georgia in 2008, or annexation of the Crimea from Ukraine in 2014 work well to keep Russias influence in the region and prevent these countries' access to NATO. Although we never know for sure whether destabilization of Georgia and Ukraine was a cause or a consequence of both countries' failure to join NATO, it is strongly believed in Moscow that such card-playing is a key to preserving Russia's sphere of interests. What does it mean for Europe?

First and foremost, it is ruining European security arrangements, which have long been based on non-use of force, freedom of choice, and normative power. With Russian revisionism on the rise, none of these are the case any longer. The Transnistrian "frozen conflict" was initially an exception to the European security system, but by now it is becoming commonplace. After succeeding in annexation of territories and creating quasi-states out of nowhere, Russia will not only further destabilize Eastern Europe, but also undermine key principles of European security, which have been in place since the end of World War II. In such a case security risks in Europe, including secessionism, terrorism, and hybrid warfare, will be multiplied.

For quite a long time, the EU's attempts to construct common foreign and security policy have been based on democratic values, economic and financial capabilities, and attractiveness of its way of life - what is called "soft power". Inability to check the Russian challenge will result in a quick depreciation of that. Arms races, military build-ups, suspicion, and mistrust will form a new system of axes in Europe. It is already taking place, although on a small scale. New realities in security arrangements are being tested in the East of Ukraine, and the experiment is going to demonstrate the most likely ways of further development. 
Russia’s immediate neighborhood faces even higher risks. Countries like Georgia and Ukraine have already suffered loss of territories. Others are defenseless, and their security depends mostly not on their actions and choice, but on Russia's intentions. That is a poor foundation for any regional security system. If a new reality, imposed by the Kremlin, comes into force, Europe as a whole will become a much more dangerous place. On the other hand, a stable, democratic, and effective Ukraine will be the biggest possible contribution to European security, just as a weak and vulnerable Ukraine will be the most serious challenge to it.

\begin{abstract}
The article addresses causes, effects, and ways of managing the crisis in and over Ukraine, which started with uprisings in Kiev and continued with Russian annexation of the Crimea and triggering internal conflict in the Donbas. Regional implications of the Ukrainian crisis are specifically targeted, while broader consequences for European security are examined through a change of the security paradigm prism.
\end{abstract}

Keywords: Ukrainian crisis, Realpolitik, Russian revisionism, European security, frozen conflicts, weak states

\title{
Zarządzanie kryzysem ukraińskim - wyzwanie dla bezpieczeństwa europejskiego
}

Abstrakt: Artykuł koncentruje się na przyczynach, konsekwencjach i koncepcjach zarządzania kryzysem na Ukrainie (i wokół Ukrainy), który rozpoczął się wraz z "rewolucją” w Kijowie i pogłębił po aneksji Krymu. Wpływ na ten kryzys ma także wywołany przez Rosję wewnętrzny konflikt w Donbasie. Tekst odnosi się głównie do regionalnych implikacji kryzysu ukraińskiego i jego konsekwencji dla bezpieczeństwa europejskiego, analizowanych przez pryzmat zmiany paradygmatu bezpieczeństwa.

Słowa kluczowe: kryzys ukraiński, Realpolitik, rewizjonizm rosyjski, bezpieczeństwo europejskie, zamrożone konflikty, państwa słabe

\section{Управление украинским кризисом - вызов для европейской безопасности}

Аннотация: Статья фокусируется на причинах, последствиях и концепциях управления кризисом в Украине (и вокруг Украины), который начался вместе с «революцией» в Киеве и углубился после аннексии Крыма. На этот кризис повлиял также вызванный Россией внутренний конфликт на Донбассе. Текст относится преимущественно к региональным последствиям украинского кризиса и его влиянии на европейскую безопасность, анализированных через призму изменения парадигмы безопасности.

Ключевые слова: украинский кризис, Realpolitik, российский ревизионизм, европейская безопасность, замороженные конфликты, слабые государства 
Pobrane z czasopisma Wschód Europy http://journals.umcs.pl/we

Data: 26/04/2023 13:24:52

\section{Bibliography}

Axelrod R., Keohane R., Achieving Cooperation Under Anarchy: Strategies and Institutions, "World Politics" 1985, Vol. 38, No. 1.

Democracy Index 2010. Democracy in Retreat. A Report from the Economist Intelligence Unit, https:// graphics.eiu.com/PDF/Democracy_Index_2010_web.pdf.

Kapitonenko M., Resolving Post-Soviet "Frozen Conflicts": Is Regional Integration Helpful?, "Caucasian Review of International Affairs" 2009, Vol.3, No.1.

Lindberg N., Stuart A. (eds.), Regional Integration: Theory and Research, Cambridge MA: Harvard University Press, 1971.

Morgenthau H., Politics Among Nations, New York 1960.

Rotberg R. (ed.), When States Fail: Causes and Consequences, Princeton 2003. 